贯 評

\title{
Atlas of the vertebrate brain: morphological evolution from cyclostomes to mammals.
}

\author{
Shiro Igarashi and Toshiro Kamiya
}

(1972, 東京大学出版会)

とのアトラスは, ヤツメウナギから人間 までの主な脊雄動物の脳を, その外観の写 真と切片の顕微鏡写真によって図解したも のである。とりあげられた動物は脊椎動物 の系統発生樹の全分枝にわたって掞り，円 口綱, 魚綱, 両生綱, 爬虫網, 鳥綱扔よび 哺乳綱のかから約85種が選ばれている。そ して原則として, 各動物とも, 脳の外観に ついてはその背面, 腹面, 側面, 正中矢状 断面抽よび可能な場合には頭蓋の夭状断面 の写真が, また脳の切片については脊㵦, 延 䟦, 橋, 中脳, 間脳および終脳のそれぞれか らの標本の顕微鏡写真が掲載されている。 その数は, 合計すると外観の写真が297枚, 切片の顕微鏡写真は247枚に達している。

脊椎動物の脳の進化についての比較解剖 学の重要性は古くから認識されていたにも かかわらず，てのように系統的かつ幅広く 扱った書物は皆無に近い。その理由は, 適 当な脳の標本を大手するととがきわめて困 難であるからに他ならない。とのアトラス の著者である東京大学医学部解剖学教室の 五十嵐至朗助教授扎よび神谷敏郎講師も珍 らしい動物の脳を入手するうえになみなみ なら双苦学をされたようである。過去 10 年 以上にわたり，日本各地の動物園の獣医諸 氏とわたりをつけ，めぼしい動物が死奴た びにその脳を集めててられたとのととであ った。また著者らが海外へ出張された折り
亿持ち州られた珍らしい標本も少なくない ようでたとえばガンジス川のカワイルカ の脳などはその代表的なものであろう。ま た, このアトラスに掲載されている脸の切 片の顕微鏡写真の約 3 分の 2 は, 同解剖学 教室および脳研究施設の小川鼎三, 細川宏, 草間敏夫の各教授らが長年にわたって集積 されてきたものとのてとであって，その意 味でこの書は著者らを含めた東京大学解剖 学教室の伝統とチームワークの成果である というととができよう。ととに，てれら諸 氏のたりまざるど努力にたいし深甚な敬意 を表する。

さて，とのアトラスの利用法であるが, まず考えられるととは, 動物の脳を刺激し たり，破壊したりする実験の際にその部位 を定位するための手引きとして役立つであ ろう。とくにとのアトラスには，八ト，ウ サギ，ハッカネズミ，イヌなど，類書の稀 な動物についても比較的詳細な切片の写真 が載せられているので，乙れらの動物の脳 足取扱うときには特別有用である。またも う一つの利用法としては, 春椎動物の脳の 進化它説明したり，さまざまの動物の脳を 比較する場合などの教材としてもきわめて 有用であろう。しかし，とういった実際的 な利用を考えなくても，ただ見るだけで楽 しい, 装幀も内味もともに凝っていて, 酒 落た本である。

（今村護郎） 